\title{
Efektivitas Penerapan Model Pembelajaran Quantum Teaching Terhadap Kemampuan Komunikasi Matematis Siswa
}

\author{
Nurbiah $^{1)}$, Andi Halimah ${ }^{2)}$, St. Hasmiah Mustamin ${ }^{3)}$ \\ ${ }^{123}$ Fakultas Tarbiyah dan Keguruan UIN Alauddin Makassar \\ nsalamang@gmail.com ${ }^{l)}$, andi.halimah@uin-alauddin.ac.id ${ }^{2}$, ,st.hasmiah.mustamin@uin-alauddin.ac.id ${ }^{3)}$
}

\begin{abstract}
Abstrak
Penelitian ini bertujuan untuk mengetahui 1) perbedaan kemampuan komunikasi matematis siswa kelas VII SMP Negeri 3 Sungguminasa Kab. Gowa yang diajar dengan model pembelajaran quantum teaching dan tanpa menggunakan model pembelajaran quantum teaching, 2) efektifvitas model pembelajaran quantum teaching dan tanpa menggunakan model pembelajaran quantum teaching terhadap kemampuan komunikasi matematis siswa kelas VII SMP Negeri 3 Sungguminasa Kab. Gowa. Penelitian ini merupakan jenis penelitian eksperimen dengan desain penelitian yang digunakan adalah quasi experimental design, yaitu non-equivalent control group design. Populasi dalam penelitian ini adalah seluruh siswa kelas VII SMP Negeri 3 Sungguminasa Kabupaten Gowa yang berjumlah 349 siswa dengan teknik pengambilan sampel menggunakan purposive sampling. Penelitian ini dilakukan pada kelas eksperimen (kelas VIIF) diajar dengan model pembelajaran quantum teaching dan pada kelas kontrol (kelas VIIG) diajar tanpa menggunakan model pembelajaran quantum teaching. Berdasarkan hasil pengujian hipetosis diperoleh hasil bahwa terdapat perbedaan antara penerapan model pembelajaran quantum teaching dengan pembelajaran tanpa model pembelajaran quantum teaching terhadap kemampuan komunikasi matematis siswa kelas VII SMP Negeri 3 Sungguminasa Kabupaten Gowa dan uji efektivitas diperoleh bahwa pembelajaran dengan model quantum teaching lebih efektif dibandingkan dengan pembelajaran tanpa menggunakan model quantum teaching kemampuan komunikasi matematis siswa kelas VII SMP Negeri 3 Sungguminasa Kab. Gowa
\end{abstract}

Kata Kunci: Kemampuan Komunikasi Matematis, Quantum Teaching

\section{Pendahuluan}

Pada dasarnya pendidikan merupakan proses untuk membantu manusia dalam mengembangkan potensi dirinya sehingga mampu menghadapi setiap perubahan yang terjadi. Pendidikan diharapkan mampu membentuk individu yang berkompetensi dan mampu membawa perubahan bagi bangsa. Tujuan pendidikan dan pengajaran ialah membentuk manusia susila yang cakap dan warga negara yang demokratis serta bertanggung jawab tentang kesejahteraan masyarakat dan tanah air (Sardiman, 2014). Salah satu mata pelajaran yang dipelajari dalam dunia pendidikan yaitu matematika. Salah satu hasil belajar matematika adalah kemampuan komunikasi matematis. Matematika merupakan salah satu komponen yang memiliki peranan penting dalam pendidikan (Kurnia Eka Lestari, 2015: 83). Tujuan diberikannya pelajaran matematika di sekolah, yaitu untuk membekali peserta didik dengan kemampuan berpikir logis, analitis, kreatif dan sistematis dan kemampuan berpikir tersebut sangat membantu siswa untuk menyelesaikan berbagai masalah dalam kehidupan (Afidah, 2014).

Selain kemampuan tersebut ada juga kemampuan komunikasi matematis siswa. Kemampuan komunikasi matematis adalah kemampuan menyampaikan gagasan atau ide matematis, baik secara lisan maupun tulisan serta kemampuan memahami dan menerima gagasan atau ide matematis orang lain secara cermat, analisis, kritis, dan evaluasi untuk mempertajam pemahaman. Indikator kemampuan komunikasi matematis yaitu, (1) menghubungkan benda nyata, gambar, dan diagram ke dalam ide matematika. (2) menjelaskan ide, situasi, da relasi matematika secara matematika secara lisan maupun tulisan, dengan benda nyata, gambar, grafik, dan aljabar. (3) menyatakan peristiwa sehari-hari dalam bahasa matematika. (4) mendengar, diskusi, dan menulis tentang matematika. Kemampuan komunikasi matematis adalah kemampuan menyampaikan gagasan atau ide matematis, baik secara lisan maupun tulisan serta kemampuan memahami dan menerima gagasan atau ide matematis orang lain secara cermat, analisis, kritis, dan evaluasi untuk mempertajam pemahaman (Bonsu I. Ansari, 2016 :33-36). Namun sampai saat ini masih banyak siswa yang bepikiran bahwa 
matematika merupakan mata pelajaran yang paling sulit dan tidak menyenangkan.Salah satu hal yang membuat siswa beranggapan bahwa matematika merupakan mata pelajaran sulit yaitu banyaknya rumus yang terdapat dalam pelajaran matematika yang mesti dihafal dan pahami sehingga akhirnya siswa tidak terlibat secara aktif dalam pembelajarannya. Kenyataan ini berdampak pada hasil belajar matematika siswa yang masih tergolong rendah dalam setiap tahunnya khususnya kemampuan komunikasi matematis siswa. Siswa yang tidak dilibatkan untuk aktif dalam pembelajaran, dapat menyebabkan siswa sulit untuk bereksplorasi, berkreatifitas terhadap ide-ide yang mereka miliki khususnya ide-ide matematika. Proses pembelajaran seperti ini menjadikannya tidak komunikatif dan tidak mempunyai keterampilan mengembangkan dirinya (Azis, 2017).

Berdasarkan hasil observasi yang dilakukan di SMP Negeri 3 Sungguminasa Kabupaten Gowa, menunjukkan bahwa sebagian besar siswa hanya memperhatikan dan mengikuti intruksi guru tanpa adanya umpan balik yang diberikan, siswa mengalami kesulitan dalam mengomunikasikan pokok-pokok permasalahan yang terdapat di dalam soal yang diberikan oleh guru dalam bentuk lisan maupun tertulis serta menuliskannya dalam bentuk permodelan matematika. Berdasarkan hasil wawancara dengan salah seorang guru mata pelajaran matematika kelas VII, mengatakan bahwa pengalaman belajar matematika yang masih minim, banyak siswa yang menganggap menyelesaikan soal-soal cerita itu memusingkan terlebih untuk menemukan solusi yang tepat untuk menyelesaikannya, kurangnya minat siswa untuk mempelajari matematika. Selain itu, juga mengalami kesulitan dalam bertanya dan menjawab pertanyaan yang diberikan oleh guru.

Hal tersebut terbukti bahwa $75 \%$ siswa tidak mampu menjawab soal matematika ketika guru mengubah bentuk soal dengan masalah yang sama. Mereka hanya menghafal rumus namun tidak mampu mengaplikasikannya. Matematika dianggap mata pelajaran yang rumit dan susah dipahami karena contoh dan soal yang diberikan berbeda namun kenyataannya sama saja. Hal tersebut menyebabkan seringkali diadakan remedial agar nilai peserta didik dapat memanuhi kriteria ketuntasan minimal 70. Hal ini menyebabkan proses pembelajaran masih cenderung pasif dan siswa kurang kreatif. Salah satu penyebab siswa memiliki kemampuan matematika khususnya kemampuan komunikasi matematis yang rendah adalah kurang tepatnya model pembelajaran yang digunakan. Oleh karena itu, guru perlu menerapkan model, pendekata, atau strategi yang sesuai dengan karakteristik siswa yang diajarnya. Adapun model pembelajaran yang dianggap bisa dan sesuai dengan karakteristik siswa di SMPN 3 Sungguminasa adalah model pembelajaran quantum teaching. Nilai dan ijazah atau sertifikat menjadi ukuran keberhasilan yang pada akhirnya pembelajaran merasa bahwa belajar dan sekolah merupakan beban, seiring dengan perkembangan dunia pendidikan, ditemukan sebuah pendekatan pembelajaran yang disebut quantum teaching (Yuberti, 2014).

Quantum pertama kali ditemukan oleh Max Planck pada akhir abad ke-19. Ia menemukan sebuah rumus fisika yang sahih yang dapat menanggulangi bencana ultraviolet (Muit Said, 2013:2021). Menurut Bobby DePorter dkk, asas utama quantum taeching adalah "bawalah dunia mereka ke dunia kita dan antarkan dunia kita ke dunia mereka". Dari asas utama ini , dapat disimpulkan bahwa langkah awal yang harus dilakukan dalam pengajaran yaitu mencoba memasuki dunia yang di alami oleh peserta didik. "Dunia kita" diperluas mencakup tidak hanya para siswa , tetapi juga guru (Muit Said, 2013:26). Jika layak dipelajari, layak pula dirayakan, kita harus memberi pujian pada siswa yang terlibat aktif pada pelajaran.Misalnya saja kita memberikan tepuk tangan berkata baik, bagus dan lain sebagainya. Quantum teaching merupakan proses pembelajaran dengan menyediakan latar belakang dan strategi untuk meningkatkan proses belajar mengajar mejadi menyenangkan (Muit Said, 2013:20-21). Pembelajaran quantum teaching mencakup petunjuk untuk menciptakan lingkungan 
belajar yang efektif merancang pengajaran, menyampaikan isi dan memudahkan proses belajar. Dengan menghadapkan siswa pada model pembelajaran quantum teaching terhadap kemampuan komunikasi matematis, kegiatan pembelajaran yang menarik akan mendapat perhatian siswa yang selama ini tidak memperhatikan. Dengan pemilihan model pembelajaran quantum teaching, peneliti berharap dapat meningkatkan kemampuan komunikasi matematis.

\section{Metode Penelitian}

Jenis penelitian ini adalah penelitian eksperimen. Penelitian eksperimen adalah penelitian yang diberi perlakuan (treatment) dan sebagai metode penelitian yang digunakan untuk mencari pengaruh perlakuan tertentu terhadap yang lain dalam kondisi yang terkendali (Sugiyono, 2015). Desain penelitian yang digunakan adalah non-equivalent control group design. Penelitian ini dilakukan di SMP Negeri 3 Sungguminasa Kabupaten Gowa. Populasi adalah sumber data dalam penelitian tertentu yang memiliki jumlah banyak dan luas (Darmawan, 2013). Populasi dalam penelitian ini adalah seluruh siswa kelas VII SMP Negeri 3 Sungguminasa Kabupaten Gowa tahun ajaran 2017-2018.Tekhnik pengambilan sampel yang digunakan adalah purposive sampling. Sampel yang digunakan pada penelitian ini yaitu kelas VII F sebagai kelas kontrol dan kelas VII G sebagai kelas eksperimen.

Pengumpulan data pada penelitian ini dilakukan dengan penggunaan tes berupa pretest (tes awal) yang digunakan untuk mengetahui kemampuan komunikasi matematis siswa sebelum penerapan model pembelajaran quantum teaching. Selanjutnya posttest (tes akhir) digunakan untuk mengetahui kemampuan komunikasi matematis siswa setelah penerapan model pembelajaran quantum teaching. Tes dibuat sendiri oleh peneliti dalam bentuk essay dengan mengikuti indikator kemampuan komunikasi matematis siswa yang terdiri dari 1) menghubungkan benda nyata, gambar, dan diagram ke dalam ide matematika. (2) menjelaskan ide, situasi, da relasi matematika secara matematika secara lisan maupun tulisan, dengan benda nyata, gambar, grafik, dan aljabar. (3) menyatakan peristiwa sehari-hari dalam bahasa matematika. (4) mendengar, diskusi, dan menulis tentang matematika. Selanjutnya dalam penelitian ini, ada 2 lembar observasi yang digunakan yaitu lembar observasi aktivitas siswa dan lembar observasi aktivitas guru pada saat pembelajaran.

Pengolahan data hasil penelitian digunakan dua tekhnik statistik yaitu statistik deskriptif dan statistik inferensial.Analisis statistik deskriptif berfungsi untuk mengetahui gambaran secara umum kemampuan pemahaman konsep matematika dan pengetahuan awal siswa. Analisis statistik inferensial digunakan untuk menguji hipotesis penelitian dengan menggunakan uji independent sample t-test dan uji efesiensi relatif, namun sebelumnya dilakukan terlebih dahulu uji normalitas dan uji homogenitas sebagai uji prasyarat.

\section{Hasil}

Berikut ini adalah tabel hasil analisis deskripsi kemampuan komunikasi matematis siswa kelas VII SMP Negeri 3 Sungguminasa Kab. Gowa yang diajar menggunakan model pembelajaran quantum teaching.

Tabel 1. Deskripsi Pretest dan Posttest Kelas Eksperimen

\begin{tabular}{ccccccc}
\hline & N & Minimum & Maximum & Mean & Std. Deviation & Variance \\
\hline Pretest Eks & 31 & 20 & 55 & 34.13 & 11.144 & 124.183 \\
Posttest Eks & 31 & 71 & 100 & 87.13 & 7.437 & 55.316 \\
$\quad$ Valid & 31 & & & & & \\
\hline
\end{tabular}


Berdasarkan tabel 1 di atas dapat dikatakan bahwa nilai pretest pada kelas eksperimen mempunyai skor maksimum 55 dan skor minimum 20 serta rata-rata yang diperoleh adalah 34,13 dengan standar deviasi 11,144dan varians 124,183 . Sedangkan nilai posttest pada kelas eksperimen mempunyai skor maksimum 100 dan skor minimum 71 serta rata-rata yang diperoleh adalah 87,13 dengan standar deviasi 7,437 dan varians 55,316. Berdasarkan hasil pretest dan posttest pada kelas eksperimen diperoleh bahwa selisih rata-rata skornya sebesar 53. Hasil tes kemampuan komunikasi matematis siswa pada kelas eksperimen dikelompokkan dalam kategori sangat rendah, rendah, sedang, tinggi, sangat tinggi akan diperoleh frekuensi dan presentase setelah dilakukan pretest dan posttest dimana dimasukan ke dalam kategori kelompok sebagai berikut:

Tabel 2. Distribusi Frekuensi dan Persentase Pretest Tingkat Kemampuan Komunikasi Matematis Kelas Eksperimen

\begin{tabular}{clcc}
\hline Tingkat Kemampuan & & Kategori & \multicolumn{2}{c}{ Pretest } \\
\cline { 3 - 4 } & & Frekuensi & Persentase \\
\hline $20-27$ & Sangat rendah & 13 & 41,94 \\
$28-34$ & Rendah & 3 & 9,68 \\
$35-41$ & Sedang & 5 & 16,13 \\
$42-48$ & Tinggi & 7 & 22,58 \\
$49-55$ & Sangat tinggi & 3 & 9,68 \\
\hline & Jumlah & 31 & 100 \\
\hline
\end{tabular}

Berdasarkan pada tabel 2 di atas maka dapat diketahui bahwa tingkat kemampuan komunikasi matematis siswa pada kelompok eksperimen pretest persentase terendah berada pada kategori rendah sebesar 9,68\% dan persentase tertinggi berada pada kategori sangat rendah sebesar $41,94 \%$. Jadi, dapat disimpulkan bahwa tingkat kemampuan komunikasi matematis siswa pretest pada kelas eksperimen berada pada kategori sangat rendah.

Tabel 3. Distribusi Frekuensi dan Persentase Posttest Tingkat Kemampuan Komunikasi Matematis Kelas Eksperimen

\begin{tabular}{clcc}
\hline Tingkat Kemampuan & & Kategori & \multicolumn{2}{c}{ Posttest } \\
\cline { 3 - 4 } & & Frekuensi & Persentase \\
\hline $71-77$ & Sangat rendah & 3 & 12,90 \\
$78-83$ & Rendah & 5 & 9,68 \\
$84-88$ & Sedang & 12 & 16,13 \\
$89-94$ & Tinggi & 7 & 38,71 \\
$95-100$ & Sangat tinggi & 31 & 22,58 \\
\hline
\end{tabular}

Berdasarkan pada tabel 3 di atas maka dapat diketahui bahwa tingkat kemampuan komunikasi matematis siswa pada kelompok eksperimen posttest persentase terendah berada pada kategori rendah sebesar 9,68\% dan persentase tertinggi berada pada kategori tinggi sebesar 38,71\%. Jadi, dapat disimpulkan bahwa tingkat kemampuan komunikasi matematis siswa posttest pada kelas eksperimen berada pada kategori tinggi. 
Hasil analisis deskripsi kemampuan komunikasi matematis siswa kelas VII SMP Negeri 3 Sungguminasa Kab. Gowa yang diajar tanpa menggunakan model pembelajaran quantum teaching.

Tabel 4. Deskripsi Pretest dan Posttest Kelas Kontrol

\begin{tabular}{ccccccc}
\hline & N & Minimum & Maximum & Mean & $\begin{array}{c}\text { Std. } \\
\text { Deviation }\end{array}$ & Variance \\
\hline Pretest Kon & 29 & 24 & 53 & 34.07 & 8.026 & 64.424 \\
Posttest Kon & 29 & 64 & 93 & 80.14 & 9.003 & 81.052 \\
\hline Valid & 29 & & & & & \\
\hline
\end{tabular}

Berdasarkan tabel 4 di atas dapat dikatakan bahwa nilai pretest pada kelas kontrol mempunyai skor maksimum 53 dan skor minimum 24 serta rata-rata yang diperoleh adalah 34,07 dengan standar deviasi 8,026 dan varians 64,424 . Sedangkan nilai posttest pada kelas kontrol mempunyai skor maksimum 93 dan skor minimum 64 serta rata-rata yang diperoleh adalah 80,14 dengan standar deviasi 9,003 dan varians 81,052 . Berdasarkan hasil pretest dan posttest pada kelas kontrol diperoleh bahwa selisih rata-rata skornya sebesar 46,07.

Tabel 5. Distribusi Frekuensi dan Persentase Pretest Tingkat Kemampuan Komunikasi Matematis Kelas Kontrol

\begin{tabular}{clcc}
\hline Tingkat Kemampuan & \multicolumn{1}{c}{ Kategori } & \multicolumn{2}{c}{ Pretest } \\
\cline { 3 - 4 } & & Frekuensi & Persentase \\
\hline $24-30$ & Sangat rendah & 11 & 37,93 \\
$31-36$ & Rendah & 9 & 31,03 \\
$37-41$ & Sedang & 2 & 6,90 \\
$42-47$ & Tinggi & 6 & 20,69 \\
$48-53$ & Sangat tinggi & 1 & 3,45 \\
\hline & Jumlah & 29 & 100 \\
\hline
\end{tabular}

Berdasarkan pada tabel 5 di atas maka dapat diketahui bahwa tingkat kemampuan komunikasi matematis siswa pada kelompok kontrol pretest persentase terendah berada pada kategori sedang sebesar 6,90\% dan persentase tertinggi berada pada kategori sangat rendah sebesar 37,93\%. Jadi, dapat disimpulkan bahwa tingkat kemampuan komunikasi matematis siswa pretest pada kelas kontrol berada pada kategori sangat rendah.

Tabel 6. Distribusi Frekuensi dan Persentase Posttest Tingkat Kemampuan Komunikasi Matematis Kelas Kontrol

\begin{tabular}{clcc}
\hline Tingkat Kemampuan & \multicolumn{1}{c}{ Kategori } & \multicolumn{2}{c}{ Posttest } \\
\cline { 3 - 4 } & & Frekuensi & Persentase \\
\hline $64-70$ & Sangat rendah & 7 & 13,79 \\
$71-76$ & Rendah & 3 & 24,14 \\
$77-81$ & Sedang & 9 & 10,34 \\
$82-87$ & Tinggi & 6 & 31,03 \\
$88-93$ & Sangat tinggi & 29 & 20,69 \\
\hline & Jumlah & & 100 \\
\hline
\end{tabular}


Berdasarkan pada tabel 6 di atas maka dapat diketahui bahwa tingkat kemampuan komunikasi matematis siswa pada kelompok kontrol posttest persentase terendah berada pada kategori sangat rendah sebesar 13,79\% dan persentase tertinggi berada pada kategori tinggi sebesar 31,03\%. Jadi, dapat disimpulkan bahwa tingkat kemampuan komunikasi matematis siswa posttest pada kelas kontrol berada pada tinggi.

Hasil analisis perbedaan kemampuan komunikasi matematis siswa kelas VII SMP Negeri 3 Sungguminasa Kab. Gowa yang diajar dengan model pembelajaran quantum teaching dan tanpa menggunakan model pembelajaran quantum teaching

Pengujian normalitas data digunakan untuk mengetahui apakah data tersebut berdistribusi normal atau tidak, dengan kriteria pengambilan keputusan adalah jika signifikansi di bawah 0,05 maka data tersebut tidak normal dan jika signifikansi di atas 0,05 maka data tersebut berdistribusi normal.

Tabel 7. Uji Normalitas Data Kemampuan Komunikasi Matematis (One-Sample Kolmogorov-Smirnov Test)

\begin{tabular}{|c|c|c|c|c|c|}
\hline & & $\begin{array}{c}\text { Pretest } \\
\text { Eks }\end{array}$ & $\begin{array}{c}\text { Posttest } \\
\text { Eks }\end{array}$ & $\begin{array}{c}\text { Pretest } \\
\text { Kon }\end{array}$ & $\begin{array}{c}\text { Posttest } \\
\text { Kon }\end{array}$ \\
\hline \multicolumn{2}{|l|}{$\mathrm{N}$} & 31 & 31 & 29 & 29 \\
\hline Normal & Mean & 34.13 & 87.13 & 34.07 & 80.14 \\
\hline Parameters ${ }^{a, b}$ & $\begin{array}{l}\text { Std. } \\
\text { Deviation }\end{array}$ & 11.144 & 7.437 & 8.026 & 9.003 \\
\hline Most Extreme & Absolute & 181 & .212 & .121 & .114 \\
\hline \multirow[t]{2}{*}{ Differences } & Positive & .181 & .113 & .121 & .077 \\
\hline & Negative & -.102 & -.212 & -.105 & -.114 \\
\hline \multicolumn{2}{|c|}{ Kolmogorov-Smirnov Z } & 1.006 & 1.182 & .652 & .616 \\
\hline \multicolumn{2}{|c|}{ Asymp. Sig. (2-tailed) } & .263 & .123 & .789 & .843 \\
\hline
\end{tabular}

Berdasarkan tabel 7 di atas, pada pretest kelas eksperimen diperoleh nilai signifikan untuk kolmogorov-smirnov sebesar 0,263>0,05 maka berdistribusi normal, pada posttestkelas eksperimen diperoleh nilai signifikan untuk kolmogorov-smirnov sebesar 0,123>0,05 maka berdistribusi normal. Sedangkan, pada pretest kelas kontrol nilai signifikan yaitu 0,789>0,05 maka berdistribusi normal, posttest kelas kontrol diperoleh nilai signifikan untuk kolmogorov-smirnov sebesar 0,843>0,05 maka berdistribusi normal. Uji homogenitas digunakan untuk mengetahui apakah data tersebut homogen atau tidak homogen. Kriteria pengambilan keputusannya adalah jika nilai signifikansi atau nilai probabilitas $<0,05$ maka varians dari dua kelompok data adalah tidak sama (tidak homogen) dan jika nilai signifikansi atau nilai probabilitas $>0,05$ maka varians dari dua kelompok data adalah sama (homogen).

Tabel 8. Uji Homogenitas Data Kemampuan Komunikasi Matematis (Test of Homogeneity of Variances)

\begin{tabular}{|c|c|c|c|c|}
\hline Nilai & Levene Statistic & $\mathbf{d f}_{1}$ & $\mathbf{d f}_{2}$ & Sig. \\
\hline Pretest & 5.381 & 1 & 58 & .074 \\
\hline Posttest & 1.740 & 1 & 58 & .192 \\
\hline
\end{tabular}


Berdasarkan tabel 8 di atas, test of homogeneity of variances, nilai signifikansi untuk data pretest sebesar 0,074 >0,05 dan data posttest sebesar 0,192>0,05, maka dapat dikatakan varians dari dua kelompok untuk data pretest dan data posttest adalah sama (homogen). Selanjutnya untuk mengetahui perbedaan model yang diterapkan dilakukan uji independent sample t-test. Kriteria pengambilan keputusannya adalah $\mathrm{H}_{0}$ diterima jika $-\mathrm{t}_{\alpha / 2} \leq \mathrm{t}_{0} \leq \mathrm{t}_{\alpha / 2}$ (nilai signifiknasi $>\alpha=0,05$ ) dan $\mathrm{H}_{0}$ ditolak jika $\mathrm{t}_{0}>\mathrm{t}_{\alpha / 2}$ atau $\mathrm{t}_{0}<-\mathrm{t}_{\alpha / 2}$ (nilai signifiknasi $<\alpha=0,05$ ). Pengujian dilakukan dengan menggunakan SPSS 20, hasilnya sebagai berikut:

Tabel 9. Independent Samples t-Test

\begin{tabular}{llllllr}
\hline & & \multicolumn{3}{c}{$\begin{array}{c}\text { Levene's Test for } \\
\text { Equality of Variances }\end{array}$} & \multicolumn{3}{c}{ t-test for Equality of Means } \\
Nilai & F & Sig. & t & df & Sig. (2-tailed) \\
& Equal variances & 1.740 & .192 & 3.288 & 58 & .002 \\
& assumed & & & & & \\
& $\begin{array}{l}\text { Equal variances not } \\
\text { assumed }\end{array}$ & & & 3.267 & 54.4 & .002 \\
\hline
\end{tabular}

Berdasarkan tabel 9 karena $\mathbf{t}_{0}=3,288>\mathrm{t}_{0,025 ; 58}=2,002$ atau nilai signifikansi $=0,002<\alpha=0,05$ maka dapat disimpulkan bahwa Ho ditolak. Jadi, dapat disimpulkan bahwa terdapat perbedaan antara penerapan model pembelajaran quantum teaching dengan pembelajaran tanpa model pembelajaran quantum teaching terhadap kemampuan komunikasi matematis siswa kelas VII SMP Negeri 3 Sungguminasa Kabupaten Gowa.

Selanjutnya, untuk melihat efektivitas penerapan model pembelajaran quantum teaching terhadap kemampuan komunikasi matematis siswa kelas VII SMP Negeri 3 Sungguminasa Kabupaten Gowa adalah dengan uji efesiensi relative yang disajikan dalam bentuk tabel sebagai berikut:

Tabel 10. Statistik Varians

\begin{tabular}{lll}
\hline \multirow{1}{*}{ Varians } & \multicolumn{1}{c}{ Posttest } \\
\cline { 2 - 3 } & Eksperimen & Kontrol \\
& 55.316 & 81.02 \\
\hline Efisiensi Relatif & & 0.682 \\
\hline
\end{tabular}

Berdasarkan hasil perhitungan di atas, karena $\mathrm{R}=0,682<1$ maka dapat disimpulkan relatif $\theta_{1}$ lebih efisien daripada $\theta_{2}$. Dengan kata lain, pembelajaran dengan model quantum teaching lebih efektif terhadap kemampuan komunikasi matematis siswa kelas VII SMP Negeri 3 Sungguminasa Kab. Gowa dibandingkan dengan pembelajaran tanpa menggunakan model quantum teaching kemampuan komunikasi matematis siswa kelas VII SMP Negeri 3 Sungguminasa Kab. Gowa.

\section{Pembahasan}

Berdasarkan persentase tertinggi dari hasil pretest dan posttest untuk kelas eksperimen, sebelum dilakukan pembelajaran diperoleh bahwa kemampuan komunikasi matematis siswa berada pada kategori sangat rendah dan setelah dilakukan pembelajaran dengan menggunakan model pembelajaran quantum teaching diperoleh bahwa kemampuan komunikasi matematis siswa berada 
pada kategori tinggi. Hasil ini menunjukkan bahwa terjadi peningkatan kemampuan komunikasi matematis siswa pada kelas eksperimen. Peneliti menyimpulkan bahwa hal tersebut sejalan dengan kondisi selama proses pembelajaran berlangsung. Sebelum menerapkan model pembelajaran quantum teaching sebagian besar siswa masih mengalami kesulitan dalam mengkomunikasikan ide-ide dalam materi matematika yang sedang diajarkan. Siswa yang diajar menggunakan model pembelajaran quantum teaching cenderung lebih aktif dalam proses pembelajaran karena siswa bekerja dalam kelompoknya. Siswa lebih mudah mengkomunikasikan berbagai ide-ide dalam materi matematika yang telah mereka pahami dibantu oleh guru di dalam kelas.

Suasana pembelajaran dengan model quantum teaching membantu siswa untuk mengembangkan kemampuan komunikasi matematis terlebih bagi siswa yang mengalami kesulitan dalam mengkomunikasikan ide matematika yang mereka pahami, melalui model pembelajaran quantum teaching ini siswa mampu mengeluarkan gagasan yang dimiliki dan disampaikan kepada anggota kelompok lainnya tanpa ada rasa takut salah.

Berdasarkan persentase tertinggi dari hasil pretest dan posttest untuk kelas kontrol, sebelum dilakukan pembelajaran diperoleh bahwa kemampuan komunikasi matematis siswa berada pada kategori sangat rendah dan setelah dilakukan pembelajaran dengan tanpa menggunakan model pembelajaran quantum teaching diperoleh bahwa kemampuan komunikasi matematis siswa berada pada kategori tinggi. Hasil ini menunjukkan bahwa terjadi peningkatan kemampuan komunikasi matematis siswa pada kelas kontrol.Peneliti menyimpulkan bahwa hal tersebut sejalan dengan kondisi selama proses pembelajaran berlangsung. Siswa yang diajar tanpa menggunakan model pembelajaran quantum teaching cenderung aktif dalam proses pembelajaran meskipun pembelajaran berpusat pada guru dan siswa bekerja secara individu. Kondisi ini terjadi karena pada saat pembelajaran berlangsung, guru mampu menarik perhatian siswa untuk mengikuti pembelajaran secara aktif. Salah satu cara yang dilakukan guru adalah meminta kepada siswa mengerjakan soal di depan kelas dan memberi imbalan berupa hadiah apabila pekerjaan siswa benar.

Suasana dalam pembelajaran tanpa menggunakan model pembelajaran quantum teaching sebagaimana yang telah dipaparkan di atas, dapat membantu siswa untuk mengembangkan kemampuan komunikasi matematis khususnya bagi siswa yang memiliki rasa kesulitan atau rasa malu untuk bertanya kepada gurunya apabila ada materi yang tidak dipahaminya.

Berdasarkan hasil uji hipotesis menggunakan uji independent samples t-test menggunakan SPSS 20, dapat disimpulkan bahwa terdapat perbedaan antara penerapan model pembelajaran quantum teaching dengan pembelajaran tanpa model pembelajaran quantum teaching terhadap kemampuan komunikasi matematis siswa kelas VII SMP Negeri 3 Sungguminasa Kabupaten Gowa.

Hal yang didapatkan pada penelitian ini sejalan dengan beberapa hasil-hasil penelitian terdahulu. Salah satunya penelitian yang dilakukan oleh Danaryanti dan Sari (2014). Hasil penelitiannya menunjukkan bahwa kemampuan komunikasi matematis dan hasil belajar siswa dengan menggunakan model pembelajaran quantum teaching menunjukkan hasil yang lebih baik dibandingkan dengan menggunakan model pembelajaran konvensional.

Siswa lebih antusias dalam mengikuti pembelajaran dengan menggunakan model pembelajaran quantum teaching dibandingkan dengan pembelajaran tanpa menggunakan model pembelajaran quantum teaching. Hasil ini sejalan dengan hasil uji efektivitas bahwa pembelajaran dengan model quantum teaching lebih efektif terhadap kemampuan komunikasi matematis siswa 
kelas VII SMP Negeri 3 Sungguminasa Kab.Gowa dibandingkan dengan pembelajaran tanpa menggunakan model quantum teaching kemampuan komunikasi matematis siswa kelas VII SMP Negeri 3 Sungguminasa Kab.Gowa.

\section{Kesimpulan}

Kemampuan komunikasi matematis siswa yang diajar menggunakan model pembelajaran quantum teaching berada pada kategori sangat rendah untuk pretest dan kategori tinggi pada posttest. Kemampuan komunikasi matematis siswa yang diajar tanpa menggunakan model pembelajaran quantum teaching berada pada kategori sangat rendah untuk pretest dan kategori tinggi pada posttest. Terdapat perbedaan antara penerapan model pembelajaran quantum teaching dengan pembelajaran tanpa model pembelajaran quantum teaching terhadap kemampuan komunikasi matematis siswa kelas VII SMP Negeri 3 Sungguminasa Kabupaten Gowa. Pembelajaran dengan model quantum teaching lebih efektif terhadap kemampuan komunikasi matematis siswa kelas VII SMP Negeri 3 Sungguminasa Kab. Gowa dibandingkan dengan pembelajaran tanpa menggunakan model quantum teaching kemampuan komunikasi matematis siswa kelas VII SMP Negeri 3 Sungguminasa Kab. Gowa.

\section{Daftar Pustaka}

Afidah, (2014). Matematika Dasar. Jakarta: PT Raja Grafindo Persada

Danaryanti, A \& Sari, D.P. (2014). Pengaruh Model Pembelajaran Quantum Teaching Terhadap Kemampuan Komunikasi Matematis Dan Hasil Belajar Siswa Kelas XI SMA. EDU-MAT Jurnal Pendidikan Matematika, Volume 2, Nomor 1, Pebruari 2014, hlm 29 - 36

Ansari, B.I. (2016). Komunikasi Matematik Strategi Berfikir Dan Manajemen Belajar. Banda Aceh: Yayasan PeNA Banda Aceh.

Darmawan, D. (2013). Metode Penelitian Kuantitatif. Bandung: Remaja Rosdakarya.

Lestari, E.K \& Yudhanegara, R.I. 2015. Penelitian Pendidikan Matematika. Bandung: Refika Aditama

Said, M.A. (2013). Quantum English. Makassar: Alauddian.

Sardirman. (2014). Interaksi dan Motivasi Belajar Mengajar. Jakarta: PT Rajagrafindo Persada

Sugiyono. (2015). Metode Penelitian Tindakan Komprehensif. Bandung: Alfabeta.

Suyono \& Hariyanto. (2014). Belajar dan Pembelajaran. Bandung: PT Remaja Rosdakarya

Sudjana, N. 1996. Statistika Pendidikan. Bandung: Ramaja Rosdakarya.

Yuberti. (2014). Suatu Pendekatan Pembelajaran Quantum Teaching. http://download.portalgaruda.org/article.php?article $=342257 \& v a l=7949 \& \mathrm{t}$ itle=Suatu\%20Pendekatan\%20Pembelajaran;\%20Quantum\%20Teaching September 2017). 